\title{
Family Language Policy ten years on: A critical approach to family multilingualism
}

\author{
By Rafael Lomeu Gomes
}

\author{
MultiLing - Center for Multilingualism in Society across \\ the LifespanUniversity of Oslo \\ r.l.gomes@iln.uio.no
}

\begin{abstract}
Family language policy (FLP) has been establishing itself as a field in the past decade. Yet, much of the scholarly debate around family multilingualism has remained within the boundaries imposed by Western-centric epistemologies. In order to address this issue, this article reviews FLP studies published between 2008 and 2017, and discusses accomplishments and limitations of recent publications. The main argument presented here is that a critical approach to family multilingualism might contribute to the development of FLP in an unexplored direction. More specifically, this paper shows how drawing on a decolonial approach allows for an express engagement with debates that have only been marginally tapped into in current FLP scholarship, for instance, the intersectional dimension of social categorisations such as social class, race, and gender. Furthermore, a decolonial approach provides a robust frame to examine transnational practices by reconciling perspectives that tend to privilege either the material basis of the economic relations of production, or the cultural domain as a locus where these relations gain meaning. Finally, a decolonial approach to family multilingualism takes a step towards redressing the extant underrepresentation of southern theories in sociolinguistics.
\end{abstract}

Keywords: family language policy, critical family multilingualism, decolonial approach, Southern perspective

\section{Introduction}

This article sets out to examine the development of Family Language Policy (FLP) as a field of study in the past ten years. This is done in light of recent debates in the field of Language Policy and Planning (LPP), and in multilingualism research, aiming at discussing the accomplishments and limitations of FLP, and pointing to possible directions for future research. I limit my coverage of research to between the years 2008 and 2017 for two reasons. First, the definition of FLP by King, Fogle and LoganTerry (2008) was an important turning point in the development of the field, allowing researchers who have a shared interest in language use in the home to construct a common site for promoting 
scholarly debate. Second, while more comprehensive overviews have already been published (e.g. Curdt-Christiansen 2013; Curdt-Christiansen and Lanza 2018; King 2016; King and Lanza 2017; King and Fogle 2013; King et al. 2008; Schwartz 2010; Smith-Christmas 2017; Spolsky 2012), a closer look at the shifts taking place within FLP, and in LPP and multilingualism research, permits the recognition of certain trends and limitations of FLP research done within the proposed timeframe that these overviews did not capture.

The main argument put forward here is that there are a number of issues in the field of FLP that are insufficiently accounted for in the current research frameworks that are the subject of review in this paper. Among such issues are the increasing transnational, specifically Southern, families that pose particular questions and reveal specific faultlines in much existing work. Addressing these issues appropriately in a better theoretical framework, I argue, would help to develop the field even further.

This article is structured in the following manner. I first give a brief orientation to some of the questions raised by transnational families for multilingual socialisation. This is followed by an overview of some key FLP studies published between 2008 and 2017. In conjunction with this overview, I note how many of the studies to a larger or smaller extent build on Spolsky's (2004, 2007, 2009, 2012) seminal work in LPP. I suggest that Spolsky's model is insufficient to account for the sorts of questions we need to ask of transnational families, and I offer the sketch of an alternative approach built around decolonial thinking. Finally, I propose that the engagement with the aforementioned developments, and with a decolonial approach to family multilingualism more generally, might promote the development of FLP in hitherto unexplored directions.

\section{Some issues in family language policies of transnational families}

While recent studies on family multilingualism have pushed the field of FLP in interesting and innovative directions, it is noteworthy that the theoretical frameworks with which researchers have worked remain within what could be understood as Westerncentric, canonic epistemologies. The notion of abyssal thinking put forth by Santos (2007) helps us to problematise this disjunction. Santos (2007) describes Modern Western thinking as abyssal thinking, that is, one which divides social realities in two realms: "this side of the line" and "the other side of the line" (p.45). Whatever is on this side of the line, he argues, results from the way modern Western thinking has forged social reality and, thus, reaches an ontological status not only as valid, but the only valid way of conceptualising social reality. Whatever is on the other side of the line is deliberately rendered invisible and, thus, not recognised as valid forms of living, thinking and producing knowledge. An overarching claim of this article is that much of FLP research to this date has been done "on this side of the line". That is, the predominance of canonic epistemologies in FLP (e.g. the pervasiveness of Spolsky's tripartite framework in which language policy is understood to be composed of language practices, language beliefs, and language management) obscures the lived experiences of people and theories from the global South. Following Santos (2014, 2018), the global South here is understood not only as the geographical South, whose populations have most been negatively impacted by the domination from the global North, but also pockets in the global North where certain populations have to struggle against oppressions and injustices. 
Shifting the focus of FLP in order to embrace the particular struggles of people from the global South as well as incorporating into the FLP theoretical apparatus concepts and theories stemming from this geopolitical location of knowledge production would allow us to answer questions that have not been asked in FLP studies, or examine those that have been asked but through a different perspective. For example, Veronelli (2015) proposes the notion of decoloniality of language to explore the connections between language, communication and coloniality. Particularly, investigating the linguistic dimension of the consequences of coloniality, Veronelli (2015) argues that the hierarchisation of races/ethnicities, constitutive of and emerging from coloniality/modernity (Quijano 1989), is accompanied by the idea that the means of expression employed by different peoples can also be ranked following a superior-inferior continuum.

Bringing this discussion under the scope of FLP research can open up analytical possibilities yet to be explored. Smith-Christmas (2016, 2017) proposes three prototypical contexts that have characterised research on family multilingualism: OPOL (one person, one language), immigrant community, and autochthonous community. She raises some issues for better understanding the language practices of multilingual families according to different contexts, for example, the relevance of the notion of social class to investigate OPOL practices (e.g. many families that have employed this "strategy" have been classified as middle class), or the stigma attached to the language practices of families in immigrant or autochthonous communities. I suggest that a critical approach to family multilingualism may provide a more robust theoretical framework to anchor social categorisations (such as class), as well as shed light on the nuances that differentiate migratory trajectories (i.e. South-South, South-North, NorthSouth, North-North). Such an approach could (i) help to unpack the discursive reproduction of the hierarchisation of race/ethnicity, gender, and social class in intercultural encounters of parents from the global South living in the global North (Lomeu Gomes, forthcoming); (ii) tap into the affective dimensions of the embodied experiences of being othered as people make sense of themselves as belonging to/constructing multilingual families; and (iii) challenge canonic understandings of central concepts such as "family", "language" and "policy" that are recurrently taken for granted. In the next section, I demonstrate that current FLP research has focussed on issues other than these. Then, I suggest what a critical approach to family multilingualism could look like. In the conclusion, I sum up the main points introduced in this article.

\section{Family Language Policy ten years on}

\section{Re(de)fining $F L P$}

In the past ten years, the field known as family language policy (FLP) has gained momentum, arguably due to FLP being formally defined in 2008. According to King et al. (2008: 907) FLP can be defined 'as explicit (Shohamy 2006) and overt (Schiffman 1996) planning in relation to language use within the home among family members.'

Fogle (2013: 83) has expanded this definition claiming that the decisions parents make about language use in the home are not necessarily overt and explicit, and including language learning as well as literacy practices: 'Family language policy refers to explicit and overt decisions parents make about 
language use and language learning as well as implicit processes that legitimize certain language and literacy practices over others in the home.'

In line with more recent understandings of FLP in general, the implicit and covert dimension of language policy within the home had already been stressed by CurdtChristiansen (2009: 352) who went further to include literacy practices in her definition: 'family language policy (FLP) can be defined as a deliberate attempt at practicing a particular language use pattern and particular literacy practices within home domains and among family members.'

These redefinitions attest to the dynamicity of FLP as a field of study continuously developing to encompass more nuanced understandings of the factors and processes at different levels of analysis related to language practices in the home. While these empirical developments have promoted greater awareness about certain issues and contexts that had been overlooked in the past, the epistemological and ontological horizons of FLP research have not changed much, which motivates a closer analysis of the directions in which the field has been going as well as the paths yet to be taken.

\section{Scope of this overview}

In order to define theworks to be reviewed, the publications (i.e. original research papers, introduction of thematic issues, commentaries, editorials, published monographs, edited volumes, and book chapters) had to: (a) contain the phrase family language policy/ies either in the title or as keywords in the abstract; (b) have been published between January 2008 and December 2017.

The methodological rigour evinced by the criteria above is not to be confounded with a nod towards epistemological universalism. Whilst the latter assumes that the ultimate goal of any scientific endeavour is to produce objective knowledge following positivist methods and relying on tenets such as neutrality, validity, reliability, generalisability, and reproducibility, establishing strict selection criteria for the material to be reviewed does not exempt the author from recognising that the review below is one of the many possible ways of interpreting the development of FLP as a field. Further, it should be highlighted that the inclusion and exclusion criteria proved to be a limitation because some works that are relevant for the investigation of multilingualism in the home had to be disregarded, especially works that situate themselves within 'language socialization' (e.g. Duff and May 2017; Duranti et al. 2012; Fogle 2012; He 2016), 'language revitalization' (e.g. Hinton 2013), and 'language shift and maintenance' (e.g. Bloch and Hirsch 2017; Gafaranga 2011; Kim and Starks 2010; Lane 2010). Yet another patent limitation is the focus on publications in English.

Inasmuch as these observations may sound as methodological truisms, the critical approach proposed in this article, in particular the alignment with a decolonial approach (Castro-Gómez and Grosfoguel 2007; Mignolo 2011b), motivates the explicit discussion about promoting epistemic diversity (de Souza 2014) and challenging current geopolitics of knowledge (Levon 2017). Furthermore, while postmodern and poststructural critiques also challenge the neutrality of knowledge production and promote a greater involvement with methodological and epistemological reflexivity, and researcher positionality, a decolonial approach takes yet another step and envisages the need to redress the extant erasure of voices from the global South from current sociolinguistic debates (Milani and Lazar 2017) by 
deliberately bringing to the fore such perspectives, be it by focussing on the particular struggles of peoples from the global South, or by drawing on theory developed in Southern contexts.

\section{Overview of FLP literature between 2008 and 2017}

In the last decade, scholars have published comprehensive overviews of the field, thematic issue introductions, and editorials, covering a wide chronological range, epistemological and methodological shifts, and remarked its empirical development (e.g. CurdtChristiansen 2013; Curdt-Christiansen and Lanza 2018; King 2016; Li Wei 2012; Spolsky 2012; King and Lanza 2017; King et al. 2008; King and Wright 2013; Schwartz 2010; Smith-Christmas 2017).

The interweaving of overviews of FLP with my own analysis of publications in the past ten years allows for an understanding of development of the field in a somewhat cohesive fashion, mainly considering three trends: (i) the pervasiveness of Spolsky's framework; (ii) the gain of currency of ethnographic methods; and (iii) the diversity of languages, geographical locations, family configurations. I now turn to a more in-depth discussion of each of these trends.

\section{Spolsky's framework}

King et al. (2008) conceive of FLP as an emerging field that brings together the fields of language policy and child language acquisition. The authors discuss how the field of language policy has shifted its initial concerns with solving the language problems of newly independent nations to trying to understand the dynamicity of the (social, cultural, and ideological) systems of which language policies are a part. It is within this understanding of the development of language policy that King et al. (2008) introduce Spolsky's (2004) framework, which envisages language policy being made of three components: language practices, language beliefs, and language management.

Likewise, Schwartz (2010: 172) suggests that 'research on family language policy (FLP) incorporates analysis of language ideology, practice and management, which were classified by Spolsky (2004) as components of the language policy model with respect to the speech community.' It is noticeable that this definition, based solely on Spolsky's (2004) model, does not include ways in which Spolsky (2007; 2009) himself further developed his theory, nor acknowledges that this model is historically situated in the development of LPP (for overviews of LPP, see Hult and Johnson 2015; Johnson and Ricento 2013; Ricento, 2000).

The restriction to an understanding of language policy based on Spolsky's framework is reinforced by Spolsky himself (Spolsky 2012) and echoed by Curdt-Christiansen (2013: 2) as she maintains that 'FLP seeks to gain insights into the language ideologies of family members (what family members believe about language), language practices (what they do with language), and language management (what efforts they make to maintain language)'.

More recent studies continue to employ Spolsky's model without critically engaging with its epistemological and ontological assumptions. For instance, Oriyama (2016) investigated how Japanese heritage youths in Australia kept contact with the Japanese language after they stopped attending heritage language schools. Besides being one of the few studies that offer a 'long-term longitudinal' (Smith-Christmas 2017: 21) perspective, another important contribution of Oriyama's (2016) study is the theoretical discussion she presents about how family, as a unit of analysis, 
can be conceptualised as a community of practice (Wenger 1998), a point first introduced by Lanza (2007). When it comes to her understanding of FLP, however, she echoes Schwartz (2010), Spolsky (2012) and Curdt-Christiansen (2013) and claims that 'FLP consists of "language ideology" (a set of beliefs in and attitudes toward a given language), "language practices" (how language is used and learned), and "language management" (specific and conscious efforts to modify and control language practices)' (Oriyama, 2016: 290).

A similar view of FLP is employed by Kang (2015) in her large-scale study involving 460 Korean parents living in the United States with their children under 18 years of age, where she attempts to develop a model to predict language maintenance in the home. Kang used an online questionnaire to collect data about participants' background information, language practice, language management and language ideology, as well as accounts of parents on their children's skills in Korean. Supporting her claims on the results of inferential statistics tests, Kang (2015) discussed the inconsistencies found between parental (positive) attitudes towards maintenance of Korean in the home and language practice and language management.

A number of other studies employ Spolsky's (2004; 2007) tripartite framework (e.g. Altman et al. 2014; Bezcioglu-Goktolga and Yagmur 2017; Chatzidaki and Maligkoudi 2013; Dumanig et al. 2013; Kaveh 2017; Kayam and Hirsch 2014; Kopeliovich 2010; Nakamura 2016; Parada 2013; Patrick et al. 2013; Pillai et al. 2014; Revis 2016; Schwartz 2008; Schwartz and Verschik 2013; Stavans 2015; Xiaomei 2017; Yu 2016) with little effort directed to evaluating the framework itself or proposing reformulations.

One of the few exceptions is Ren and Hu's (2013) attempt to improve Spolsky's model by combining its use with notions emerging from family literacy research (i.e. prolepsis, syncretism, and synergy). In another example, Tannenbaum (2012) advocates for a focus on the emotional aspects of family language policy. She proposes looking at family language policy as a defence or coping mechanism and, in doing so, she suggests that FLP research has underexplored the contributions from psychology and psychoanalysis. Tannenbaum and Yitzhaki (2016) take a step towards addressing this limitation by examining the connections between emotions and language practices of multilingual families. Additionally, Berardi-Wiltshire (2017) suggests that research on indigenous language revitalisation might benefit from drawing on Spolsky's tripartite framework as employed by FLP literature. Finally, Fogle (2013) supports the idea of expanding the ideological component of FLP to include parental beliefs not only about language, but also about 'family, childhood and caregiving' (Fogle, 2013: 99).

Despite the prevalence of Spolsky's model throughout the last ten years in FLP, some scholars have been engaging with other models or theories, particularly in the last five years. For instance, O hIfearnáin (2013) frames his mixed-method investigation of language practices and attitudes of Gaeltacht Irish speakers toward intergeneration transmission within a folk linguistics approach. Smith-Christmas (2014), in turn, situates her study about the three generations of one family involved in the use of an autochthonous minority language (i.e. Gaelic) within the field of language socialisation (Schiefflin and Ochs 1986). In addition, Purkarthofer (2017) creatively combines an understanding of the notion of linguistic repertoire informed by interactional, poststructural and phenomenological approaches (Busch, 2012) with the assumption that 
it is crucial to consider the construction of space in social analysis, which is accomplished by drawing on Lefebvre's (1991) framework of the production of space.

Finally, Gallo and Hornberger (2017) propose an ethnographic approach to language policy as a way to account for the complexity and creativity involved in the ways social actors adopt, follow or resist language policies (Hornberger and Johnson 2011). Tapping into under-researched notions and topics in FLP such as borders, securitisation, and immigration policies, Gallo and Hornberger (2017) report the case of an eight-year-old girl (Princess) and her family living in the United States, including her father who was deported to Mexico during data collection. Engaging with yet another under-explored discussion in FLP, namely how languages can be conceptualised as something other than a fixed category, the authors draw on the notion of continua of biliteracy (Hornberger 2002) to demonstrate Princess' active role on her family's migration decisions and language planning. Also, they highlight how the ethnographic approach to LPP allows uncovering the monoglossic language ideologies upon which participants draw in order to make future decisions regarding migration and schooling.

These four studies illustrate that drawing on concepts, theories and approaches other than those sustained by Spolsky's framework might contribute to developing FLP in directions that have not been much explored. More recent overviews of FLP have noticed this move away from Spolsky's model and expanded this limiting understanding of (family) language policy. For instance, King (2016: 727-8) advances the idea that research belonging to 'the fourth phase' of FLP is characterised by '[the examination of] language competence not just as an outcome, but as a means through which adults and children define themselves, their family roles, and family life; a focus on globally dispersed, transnational, multilingual populations beyond the traditional, two-parent family; and ever-greater heterogeneity and adaptability in research methods to address these shifting needs in the field.'

In the same vein, King and Lanza (2017) identify two trends in current FLP research. The first trend is characterised by the increasing attention given to demographic changes seen through a lens that draws on notions such as migration, mobility and transnationalism to better understand multilingual practices. The second trend involves a shift from examining the relationship between language input and its entailing outcomes, to investigating (rather than assuming) the contexts in which family communication takes place. A methodological implication of this shift is the increased use of ethnographic approaches, which brings us to the second point of convergence among recent overviews of FLP.

\section{The gain of currency of ethnographic methods}

The potentially limiting consequences of the affiliation to a single theoretical model (i.e. Spolsky's) as the foundation of FLP implied by Schwartz (2010) are dispelled as she presents future directions for FLP. Among other things, she stresses the importance of collecting and examining naturally occurring speech using ethnographic methods. More recent papers seem to have answered this call.

For example, in her 9-year investigation of language ideologies and practices in Oaxaca, Mexico and California, the United States, Pérez Báez (2013) used interviews and participant observation to demonstrate the influence of external factors (i.e. school and social networks) on attempts 
of families to maintain San Lucas Quiavianí Zapotec, and to unveil the language ideologies circulating within the communities under investigation. Kheirkhah and Cekaite (2015) examined the language practices of one PersianKurdish family in Swedish through video recordings, ethnographic observations and interviews. These methods allowed them to identify the different strategies used by parents in interaction with the child, and to emphasise the importance of considering children as agents in the implementation of family language policies. Children's agency was also central to Gyogi's (2015) study of two English-Japanese bilingual children and their mothers in London, UK, where she claims that children demonstrate their agency by contesting, negotiating and redefining their mothers' language beliefs.

The increasing use of ethnographic methods in FLP calls for a consideration about the extent to which Spolsky's general model and its underlying epistemological and ontological assumptions are compatible with those of ethnographic approaches to the study of language and society. Perhaps Spolsky's model is better suited for studies that aim at working with larger numbers of participants, identifying general patterns, and predicting likely outcomes. But these are generally not the concerns of ethnographies, whose focus is on gaining in-depth understandings of localised practices while locating these interpretations in longer or broader social processes (Rampton 2012).

King and Lanza (2017) point out that FLP can benefit from recent developments in socio- and applied linguistics, as well as in LPP. They suggest that LPP studies have been increasingly making use of "critical and qualitative methods' (King and Lanza 2017). However, while the popularity of qualitative and ethnographic methods is easily perceived in recent FLP scholarship (e.g. Curdt-Christiansen 2016; Schwartz and Verschik 2013; Smith-Christmas 2016; Zhu Hua and Li Wei 2016), I argue that 'critical research perspectives' (Hult and Johnson, 2015: 11) have only been employed timidly by recent FLP literature (e.g. Gallo and Hornberger 2017). Before fully developing this argument (in section 4), I discuss how overviews have treated the empirical advancements in FLP, and I present my own considerations about them.

\section{Diversity of languages, geographical locations, family configurations}

King et al. (2008) suggested that future FLP research focussed on issues related to globalisation and transnationalism as these processes might have considerable influence on language practices in the home. Curdt-Christiansen (2013: 2) shows how recent studies have explored this path as they include non-middle class, marginalized and under-studied transnational family types as well as Indigenous and endangered languages'. Furthermore, studies in what King (2016) refers to as the 'fourth phase' of FLP demonstrate a focus on family configurations other than those with two middle-class parents.

More recently, King and Lanza (2017) note both the focus on families that go beyond the traditional, twoparent model and a greater variety of languages. This is echoed by SmithChristmas (2017), who recently pointed out that although there has been an inclusion of different geographical locations where data has been collected, a strong focus on North American and European contexts still exists. In figure 1 I present the number of original FLP studies by country where data was collected. As noted, the studies had to contain the phrase "family language policy/ies" in the title or abstracts, and be published between 2008 and 2017 . 
In analysing recent developments in FLP research, Smith-Christmas (2017: 18) justly remarks that 'there is a dearth of research situated within Africa or the Middle East (apart from Israel)'. She then suggests that our understanding of language use in the family would benefit from studies that capture the experiences outside the viewpoints of Western, industrialised communities. I concur with her suggestion, and some studies have already been exploring this direction (e.g. Kendrick and Namazzi 2017; McKee and Smiler 2017; Mirvahedi 2017; Moore 2016).

While the relevance of investigating family configurations, locations and languages that we still know little about in FLP should be recognised, a critical approach to family multilingualism supports the idea that bringing voices from the global South into current sociolinguistic debates is not only a matter of changing the context of investigation, but shifting the current paradigm that renders the global North as the producer of theory and the global South as the source of data against which theories are tested (Connell 2007). Along with the need to expand the scope of FLP not only as places where data are collected, but also as geopolitical loci where knowledge is produced, there has been a need to include research that investigates the particularities of language practices by families that use non-European languages.

Table 1 illustrates that recent scholarship reviewed here (following the aforementioned criteria) has broadened the range of languages examined in FLP. While this effort attests to an important empirical advancement of the field, there exists a stronger tendency to draw on assumptions about language akin to positivist modernist sociolinguistics (García et al. 2017). That is, in general, studies seem to subscribe to ideas of languages as being units that can be delineated, separated, named and counted. Rather

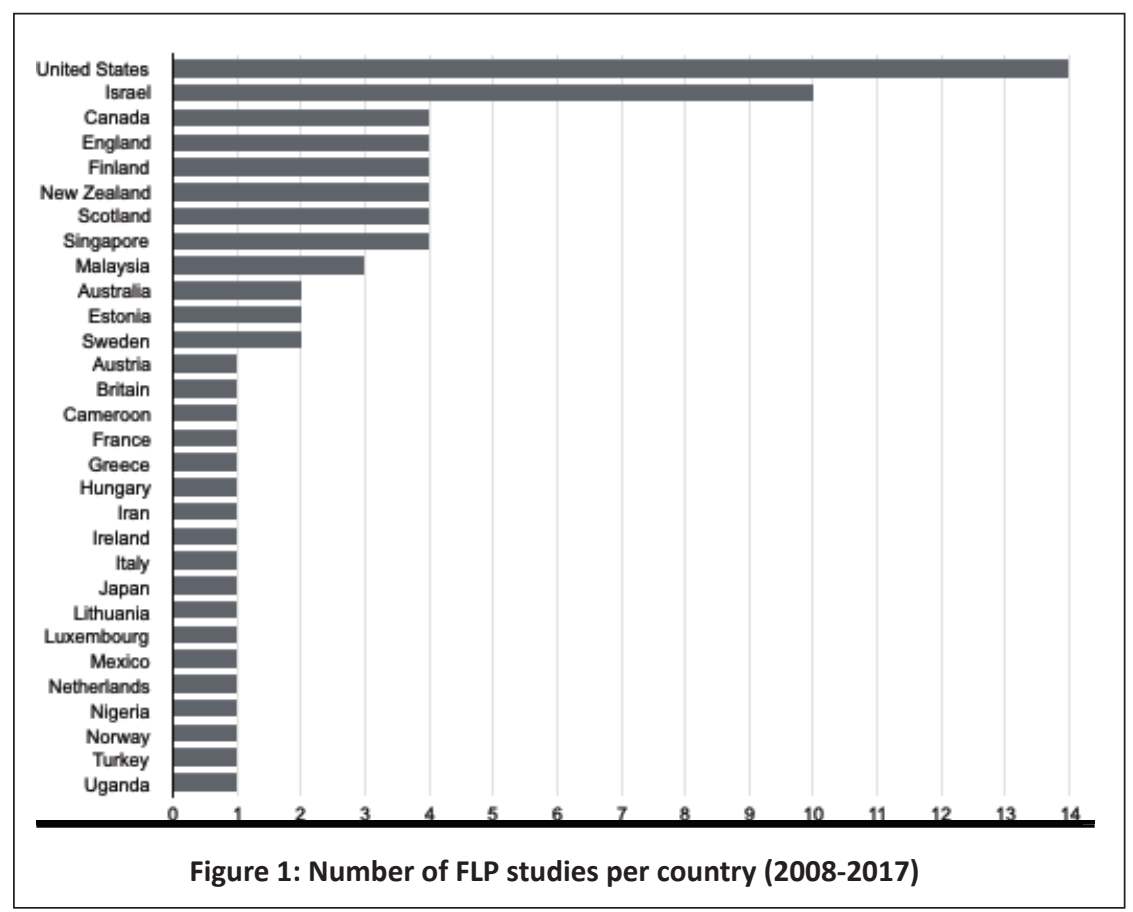


than affirming that languages are not abstract systems that can be named, differentiated and counted, the point here is that there is an important ongoing debate in socio- and applied linguistics (e.g. Canagarajah 2013; García and Li Wei 2014; Jørgensen 2008; Pennycook and Otsuji, 2015) with which recent FLP studies have not engaged.

For instance, in Seloni and Sarfati's (2013: 9) investigation of language ideologies and practices of families in Turkey, they justify the employment of the term Judeo-Spanish for it is a “"neutral, self-explanatory term" (Harris 1982: 5) embraced by most scholars working on the topic.' Interestingly, Harris (1982: 5) continues 'Others consider it a pseudoscientific term to be used only for purposes of popularization', demonstrating how naming languages is not exactly a neutral enterprise.

Another insight that table 1 yields has to do with how languages and language varieties are named. In CurdtChristiansen's (2009) study, she employs ethnographic methods to identify the values assigned to Chinese, English and French by Chinese parents in Quebec, Canada, and how these are linked to particular linguistic markets. More recently (Curdt-Christiansen 2016), in examining the language ideologies and practices of three multilingual families in Singapore, Hokkien and Mandarin (rather than the all-encompassing label Chinese) are

Table 1 - Languages* investigated by FLP studies between 2008 and 2017 (in alphabetical order)

\begin{tabular}{lll}
\hline Albanian & Ibibio & Polish \\
American Sign Language & Igbo & Punjabi \\
Amharic & Irish & Qur'anic Arabic \\
Arabic & Italian & Russian \\
Azerbaijani & Japanese & San Lucas Quiaviní Zapotec \\
Cantonese & Judeo-Spanish & Scottish Gaelic \\
Chinese & Khmer & Sinhala \\
Dutch & Korean & Spanish \\
Efik & Kurdish & Swedish \\
English & Latvian & Tagalog \\
Estonian & Lithuanian & Tagalog/Visayan \\
Farsi & Lokaa & Taiwanese \\
Finnish & Luganda & Tamil \\
French & Malacca Portuguese Creole & Teochew \\
Fulfulde & Malay & Thai \\
German & Mandarin & Turkish \\
Hakka & New Zealand Sign Language & Ukrainian \\
Hebrew & Nigerian pidgin & Urdu \\
Hokkien & Norwegian & Vietnamese \\
Hungarian & Persian & Zapotec \\
\hline
\end{tabular}

* The names of the languages are reproduced here the same way researchers used in their own works. 
the terms employed to account for the languages used at home.

Furthermore, in his survey involving 170 children in Ontario, Canada, Slavkov (2016) aimed at developing a framework capable of accounting for the factors that lead to (or prevent) bi/multilingualism. He was specifically interested in examining the roles of family language policies and school language choice in promoting bi/ multilingualism. Relying on descriptive and inferential statistics, Slavkov (2016: 17) concludes that if non-overlapping language strategies are adopted as a best practice at the family and educational levels, all children in Ontario, and potentially the rest of Canada, can become bilingual and many of them multilingual.' A concerning corollary of this proposition is its implicit idea that bi-multilingualism is inherently good, and it should ultimately be pursued, obfuscating the social, cultural, political dimensions of language practices, which should be central to sociolinguistic analysis.

The three examples above are representative of a more common tendency in FLP. While the increased use of ethnographic approaches has eschewed certain taken-for-granted notions and yielded more refined accounts of the situatedness of language practices, a central element in sociolinguistic research, namely, language has not undergone the same scrutiny. In other words, FLP literature has not been particularly successful in openly discussing the ontological status language receives in the analysis. Relatedly, most recent FLP studies have not engaged with conceptualisations that challenge the notion that languages are autonomous systems that can be separated into discrete units, named and counted. Despite the relative novelty of conceptualisations such as translingual practice (Canagarajah 2013), polylingual languaging (Jørgensen 2008; Møller and Jørgensen 2009), metrolingualism (Otsuji and Pennycook 2010; Pennycook and Otsuji 2015), translanguaging (García and Li Wei 2014; Li Wei 2018, Otheguy et al. 2015), and Spracherleben (Busch 2015), scholars (e.g. Haugen 1972; Khubchandani 1983) have discussed this for many decades, which makes the little engagement of FLP literature with these issues (but see Conteh et al. 2013) even more intriguing. It should be highlighted, however, that the employment of these notions is not regarded as a panacea (see Jaspers and Madsen 2016; Orman 2013; and Pennycook 2016). Instead, the point made here is twofold: drawing on these notions might help to elucidate issues related to family multilingualism in innovative ways; and FLP has the potential to make original contributions to the very debate about what language is.

\section{An untrodden path: A critical approach} to family multilingualism

Below I summarise certain ontological and epistemological assumptions of Spolsky's model that, I argue, engender limitations for the development of FLP. I go on to sketch how these assumptions are challenged by what has been described as critical (Pennycook 2001; 2004; Pietikäinen 2016; Roberts 2001) approaches to research on language and/ in society.

The first assumption is that 'language behavior is reflective of sociocultural patterning' (Fishman 1972: 441). This assumption is echoed by Spolsky in his claim that '[language management] is not autonomous, but the reflex of the social, political, economic, religious, ideological, emotional context in which human life goes on.' (Spolsky 2009: 9) Second, although Spolsky recognises that language varieties 'are socially or politically rather than linguistically motivated' (Spolsky 2009: 1), and 
underlines the 'sloppiness of the labels we have available' (Spolsky 2004: 161) to describe multilingual practices and multilingual contexts, the understanding of language that his model puts forth is that it is an abstract, bounded, discrete entity that can be neatly delineated, categorised and counted. Third, the salience of role relations (Fishman 1972) between participants, subsumed under the notion of domain, as opposed to perspectives which bring to the fore social categorisations such as race, ethnicity, gender, sex, class, age and ability. Fourth, while recognising the need for 'a detailed study of the faceto-face interactions in which language choice is imbedded' (Fishman 1972: 442) as a requirement to support the validity of domain as a concept, Spolsky builds his case drawing on methods other than face-to-face interactions, or other data generation tools typically employed by ethnographic approaches.

In the past two decades or so, scholars investigating issues within the fields of sociolinguistics and applied linguistics have been qualifying certain strands of research as critical (e.g. García et al. 2017; Heller 2011; MartinJones and Martin 2016; Mesthrie and Deumert 2000; Pennycook 2001; 2004). The use of this term usually denotes (a) certain epistemological stance(s) taken by researchers, along with respective ontological assumptions. I situate this article within this debate and, below, I present three ways in which FLP might benefit from drawing on a critical approach.

The term critical employed here is meant to encompass approaches that take, oftentimes, a social constructivist epistemological stance to the study of language and society, assuming that language practices and social reality are dialectically and recursively entangled. Heller (2011: 34), for example, highlights the constructive dimension of language in that it has a complex role in constructing the social organization of production and distribution of the various forms of symbolic and material resources essential to our lives and to our ability to make sense of the world around us.'

Furthermore, these approaches tend to be interested in examining social reality as a way to unveil the ways in which power and wealth are unevenly distributed in society. In what has been termed critical poststructuralist sociolinguistics (García et al. 2017), researchers tend to draw on the Foucauldian assumption that power is ubiquitously present in society (as opposed to an institutional, centralised, top-down view of power) to investigate 'language practices in interrelationship to the socio-historical, political, and economic conditions that produce them.' (García et al. 2017: 5). Moreover, authors oppose an epistemological stance that stands for the production of objective, neutral and universal knowledge systems, and champion, instead, a stance that assumes the situatedness of knowledge production (Heller 2011; Mignolo 2011b).

Also building on Foucault (1969; 1975) to account for the relations of power, Heller (2011) draws on a historical materialist approach, stressing the need for sociolinguistic analyses to consider the material basis of social organization. She proposes a critical ethnographic sociolinguistics, which is built on two pillars: ethnography and political economy. While the former permits an understanding of language use as situated practice and its connections to social structure, the latter emphasises the need to understand the constraints imposed by material conditions on meaning-making activities (Heller 2011).

It is not uncommon for authors to go beyond exposing social inequalities and injustices, and propose ways to address such inequalities and injustices stripping away the neutrality and 
objectivity that marked the initial stages of modern social sciences and the early days of sociolinguistics in the 1960s, and unveiling the social and political roles of sociolinguistics as a discipline that could advocate 'for a more equitable future' (García et al. 2017: 6). However, the necessity for research-led social transformation is not necessarily the ultimate goal of a critical approach, as the steps that precede it might indicate possible ways of action, if any (Heller 2011).

One final aspect of the notion of critical that has motivated its use relates to a certain degree of scepticism that inspires scholars to question takenfor-granted concepts, approaches, and methods, regardless of how prevailing they are. A phrase that captures well this sceptical posture is 'the restive problematization of the given' (Dean 1994: 4, as cited in Pennycook 2004: 799). Assuming this posture is what yields the questioning of the ontological status of language supported by positivist modernist sociolinguistics (García et al. 2017). Therefore, rather than understanding languages as abstract entities that can be separated, named and enumerated, languages are thought to be 'the consequence of deliberate human intervention and the manipulation of social contexts' (García et al. 2017: 6). It is within the context of this discussion that I present how a critical approach to family multilingualism contributes to the development of FLP.

\section{What could decoloniality mean for the field of FLP?}

What if FLP research explored more explicitly the implications of taking a stance that considers the relationship between language and social reality to be mutually constitutive of one another, rather than unidirectional? What if family multilingualism is theorised through conceptualisations that expand (or squarely challenge) notions of language as abstract, separable, and countable systems? To what extent can ethnographic methods be employed cohesively with Spolsky's framework? In sum: what if the interdisciplinary nature of FLP promoted an engagement with pressing discussions in socio- and applied linguistics (e.g. Busch 2015; Canagarajah 2013; Jørgensen 2008; Li Wei 2018; Pennycook and Otsuji, 2015), LPP (e.g. Hult and Johnson 2015; Johnson and Ricento 2013; Ricento 2000) and social sciences (e.g. CastroGómez and Grosfoguel 2007, Connell 2007; Mignolo 2011b; Santos 2014) that have not been thoroughly explored in recent FLP studies?

Rather than providing definite answers, I aim at opening up a discussion about the limitations of FLP as a field and possible ways to push, transgress or erase its boundaries. To this end, I propose a critical approach to family multilingualism. Particularly, I argue that a decolonial approach to the study of family multilingualism offers a perspective which underscores the intersectional dimension of social categorisations such as gender, race and class, while attending to the political and economic dimensions of the transnational centre-periphery divide. Furthermore, such an approach takes a step towards disrupting the current unbalance of geopolitics of knowledge, foregrounding Southern perspectives in the analysis of language practices.

The effort made by researchers to contribute to the development of FLP by investigating a great variety of contexts is, indeed, laudable. Along with the increased use of ethnographic methods, the expansion of scope in terms of languages, countries and family configurations can have a substantial impact on FLP literature, and possibly beyond, as it may yield more in-depth understandings about the situatedness 
of language practices. Notwithstanding, this push of boundaries of the empirical scope of FLP research can only go so far if epistemological and ontological shifts do not accompany it. Put differently, FLP as a field can have its development severely restricted if it draws solely (or mostly) on notions of languages as fixed category. One way to overcome this limitation would be to draw on conceptualisations of language presented in section 3 , and investigate their suitability for the study of language use in the home.

Furthermore, despite engaging with discussions such as the demographic, economic and political implications of transnationalism and globalization - mainly through a political economy analysis, though not always explicit - there has not been significant and express engagement with theoretical frameworks that assume the complexity, heterogeneity and fluidity of cultures (e.g. Ahmed 2000; Anzaldúa 1987; Appadurai 1996; Bhabha 1994). Finally, as long as the relevance of investigating families that go beyond the 'traditional, two-parents model' is framed within a logic of 'denial of coevalness' (Fabian 1983), FLP as a field of inquiry might restrict itself to a liberal understanding of diversity (Kymlicka 1995), and overlook debates that shed light on issues such as social class (Block, 2015), gender and sexuality (Fabrício and Moita Lopes 2015; Milani 2018), race and ethnicity, (de Melo and Moita Lopes 2015; Reyes 2017; Rosa and Flores 2017; Samy Alim et al. 2016; Williams and Stroud 2014), and disability (Grue 2016).

One way to overcome this limitation, and in line with the growing need to include southern perspectives in current sociolinguistic debates (cf. Levon 2017; Milani and Lazar 2017; García et al. 2017), the critical approach to family multilingualism proposed here draws on the works of scholars involved with the decolonial turn (Castro-Gómez and Grosfoguel 2007). Castro-Gómez and Grosfoguel (2007) claim that while the forms of domination employed by European nation-states might have changed, the structure that sustains the relations between 'central' and 'peripheral' countries remains the same. That is, despite the legal-political decolonization that has legitimated the independency of former colonies, the structures of domination based on the hierarchisation of races/ethnicities and gender/sexuality set in place in the sixteenth and seventeenth centuries are still reproduced through the international division of labour between centre and periphery, and contribute to the contemporary social and economic divide (Castro-Gómez and Grosfoguel 2007).

Additionally, while other approaches to the examination of class, gender, and races in a context of globalisation may favour the economic or the cultural domains in their analyses, a decolonial perspective envisages the entanglement between culture, and economic and political processes. Put differently, Castro-Gómez and Grosfoguel (2007) suggest that world-system analysis as put forth by Wallerstein (1991) builds on the Marxist paradigm of base/superstructure, and assumes that culture (superstructure) derives from relations of production (base). Conversely, postcolonial studies invert this relationship and support the idea that economic and political relations do not have a meaning in themselves; rather, they gain meaning in specific semiotic sites. Each approach, thus, is considered to build their analyses upon opposing ontological assumptions. Drawing on a decolonial perspective may offer reconciliation between these conflicting approaches whilst sharing some of their concerns.

Following this discussion, a critical approach to family multilingualism drawing on a decolonial approach might be useful for pushing the development of FLP in a direction that has not been 
explored. That is to say, incorporating in FLP research the propositions put forth by Castro-Gómez and Grosfoguel (2007) related to the ontological status of social categorisations allows for a useful framing of these categorisations while undertaking an analysis of family multilingualism. Moreover, the deliberate effort to draw on theorisations from the global South, particularly those related to globalisation, transnationalism and the effects of Western, modern scholarship (e.g. Castro-Gómez and Grosfoguel 2007; Kerfoot and Hyltenstam 2017; Mignolo 2011a; Mignolo 2011b; B. Santos 2014; M. Santos 2017) can inform social analysis in ways that have not been much explored in sociolinguistics in general, let alone in FLP, and shed light on debates about transnational practices, identity negotiation and language use.

Finally, an issue that is still unresolved in FLP is the extent to which certain practices can be conceived of as management (or policy) if they are covert and implicit. Curdt-Christiansen and Lanza (2018: 126) see this tension as the 'blurred distinction between the concepts of language practices and language management', while Pennycook (2017) takes a more direct stance in suggesting the irreconcilability between an understanding of language policy stemming from Fishmanian sociolinguistics (i.e. Spolky's framework) and an understanding that highlights the situatedness of language practices. I claim critical, ethnographic approaches (Martin-Jones and Martin 2016) to FLP may open up a promising site for carrying on this debate about language practices and language policy.

\section{Conclusion}

While serving as an important common ground upon which scholars with similar interests contributed to the emergence and establishment of a scientific field of inquiry, a discussion of the implications of the assumptions of Spolsky's framework is lacking in current FLP literature, unlike in LPP literature (cf. Albury 2016; and Pennycook 2017). The relevance of this discussion lies on the possibilities opened up by a critique of Spolsky's framework at a theoretical level and its implications for FLP research. Therefore, in this article I discussed the epistemological and ontological assumptions of Spolky's framework, and the potentially limiting implications of its pervasiveness in recent FLP literature.

However, because Spolsky's model draws largely on tenets supported by Fishmanian sociolinguistics, it holds certain assumptions that are difficult to reconcile with critical approaches to the investigation of family multilingualism. I showed that some FLP studies are already going beyond Spolsky's framework, either by trying to expand it or by drawing on different theoretical frameworks. Additionally, I suggested that drawing on recent debates about how language can be conceptualised may be a productive path to follow in studying language practices in the home. Finally, I showed how a decolonial approach to family multilingualism might lead to original discussions about issues that have not been much explored in recent FLP literature.

A potential complication of the increasing interdisciplinarity in FLP has already been raised by King (2016: 731): 'the field of family language policy risks splintering in such a way that there is diminished capacity for researchers to exchange findings, collaborate, or even make meaningful sense of others' work." However, in section four I argued for the ways in which a critical approach to family multilingualism might contribute to the development of FLP, and because of that, I suggest that the risk brought up by King (2016) is worth taking. 


\section{Acknowledgements}

A previous version of this paper was presented at the launch of the Harmonious Bilingualism Network (HaBilNet1) on May 24-25, 2018 in La Hulpe, Belgium. I should like to thank my academic supervisors Pia Lane, Elizabeth Lanza, and Alastair Pennycook for comments on earlier drafts. Also, I benefited from the constructive feedback I received from Kristin Vold Lexander, Sébastien Lucas, Maria Obojska, and Bente Ailin Svendsen. Moreover, the insightful comments from the anonymous reviewer and the editor were crucial in shaping the article into this final version. Shortcomings and mistakes are my own. This work was partly supported by the Research Council of Norway through its Centres of Excellence funding scheme, project number 223265 (MultiLing).

\section{References}

Ahmed, Sara. 2000. Strange Encounters: Embodied Others in Post-Coloniality. London: Routledge.

Albury, Nathan John. 2016. National language policy theory: Exploring Spolsky's model in the case of Iceland. Language Policy 15(4): 355-372.

Altman, Carmit, Zhanna Burstein Feldman, Dafna Yitzhaki, Sharon Armon Lotem, and Joel Walters. 2014. Family language policies, reported language use and proficiency in Russian-Hebrew bilingual children in Israel. Journal of Multilingual and Multicultural Development 35(3): 216-234.

Anzaldúa, Gloria. 1987. Borderlands/La Frontera: The New Mestiza. San Francisco: Aunt Lute Books.

Appadurai, Arjun. 1996. Modernity at Large: Cultural Dimensions of Globalization (vol. 1). Minneapolis: University of Minnesota Press.

Bezcioglu-Goktolga, Irem and Kutlay Yagmur. 2017. Home language policy of second-generation Turkish families in the Netherlands. Journal of Multilingual and Multicultural
Development 39(1): 44-59 doi: 10.1080/01434632.2017.1310216.

Bhabha, Homi K. 1994. Location of Culture. London: Routledge.

Bloch, Alice, and Shirin Hirsch. 2017. "Second generation" refugees and multilingualism: Identity, race and language transmission. Ethnic and Racial Studies 40(14): 2444-2462.

Block, David. 2015. Social class in Applied Linguistics. Annual Review of Applied Linguistics 35: 1-19 doi: 10.1017/ S0267190514000221.

Busch, Brigitta. 2012. The linguistic repertoire revisited. Applied Linguistics 33(5): 503-523.

Busch, Brigitta. 2015. Expanding the notion of the linguistic repertoire: On the concept of Spracherleben - The lived experience of language. Applied Linguistics 38(3): 340-358.

Canagarajah, Suresh. 2013. Translingual Practice: Global Englishes and Cosmopolitan Relations. London and New York: Routledge.

Castro-Gómez, Santiago and Ramón Grosfoguel (eds). 2007. El Giro Decolonial: Reflexiones para una Diversidad Epistémica más allá del Capitalismo Global. Bogotá: Siglo del Hombre Editores.

Chatzidaki, Aspassia and Christina Maligkoudi. 2013. Family language policies among Albanian immigrants in Greece. International Journal of Bilingual Education and Bilingualism 16(6): 675-689.

Connell, Raewyn. 2007. Southern Theory: The Global Dynamics of Knowledge in Social Science. Cambridge and Malden: Polity Press.

Conteh, Jean, Saiqa Riasat, and Shila Begum. 2013. Children learning multilingually in home, community and school contexts in Britain. In Mila Schwartz and Anna Verschik (eds). Successful Family Language Policy: Parents, Children and Educators in Interaction. Dordrecht: Springer. 83-102.

Curdt-Christiansen, Xiao Lan. 2009. Invisible and visible language planning: Ideological factors in the family language policy of Chinese immigrant families in Quebec. Language Policy 8(4): 351-375. 
Curdt-Christiansen, Xiao Lan. 2013. Family language policy: sociopolitical reality versus linguistic continuity. Language Policy 12(1): 1-6.

Curdt-Christiansen, Xiao Lan. 2016. Conflicting language ideologies and contradictory language practices in Singaporean multilingual families. Journal of Multilingual and Multicultural Development 37(7): 694-709.

Curdt-Christiansen, Xiao Lan and Elizabeth Lanza. 2018. Language management in multilingual families: Efforts, measures and challenges. Multilingua: Journal of Cross-Cultural and Interlanguage Communication 37(2): 123-130.

de Melo, Glenda Cristina Valim and Luiz Paulo da Moita Lopes. 2015. "Você é uma morena muito bonita": A trajetória textual de elogio que fere. Trabalhos em Linguística Aplicada, 54(1): 53-78.

de Souza, Lynn Mario. 2014. Epistemic diversity, lazy reason and ethical translation in post-colonial contexts: The case of indigenous educational policy in Brazil. Interfaces Brasil/Canadá, Revista Brasileira de Estudos Canadenses 14(2), 36-60.

Dean, Mitchell. 1994. Critical and Effective Histories: Foucault's Methods and Historical Sociology. London: Routledge.

Duff, Patricia and Stephen May (eds). 2017. Language Socialization (3rd edition) Springer International Publishing.

Dumanig, Francisco Perlas, Maya Khemlani David, and Thilagavathi Shanmuganathan. 2013. Language choice and language policies in FilipinoMalaysian families in multilingual Malaysia. Journal of Multilingual and Multicultural Development 34(6): 582-596.

Duranti, Alessandro, Elinor Ochs, and Bambi B. Schieffelin (eds). 2012. The Handbook of Language Socialization. Chichester: Wiley-Blackwell.

Fabian, Johannes. 1983. Time and the Other: How Anthropology Makes its Object. New York: Columbia University Press.

Fabrício, Branca Falabella and Luiz Paulo da Moita Lopes. 2015. TV-school hybrid literacy practices as sites for making another logic possible: Voicing contrasts that promote gender and sexuality trans-experiences. Cadernos de Linguagem e Sociedade 16(2):12-32.

Fishman, Joshua. A. 1972. The link between macro- and micro-sociology in the study of who speaks what to whom and when. In John J. Gumperz and Dell Hymes (eds). Directions in Sociolinguistics. New York: Holt, Rinehart \& Winston. 435-453.

Fogle, Lyn Wright. 2012. Second Language Socialization and Learner Agency: Adoptive Family Talk. Bristol: Multilingual Matters.

Fogle, Lyn Wright. 2013. Parental ethnotheories and family language policy in transnational adoptive families. Language Policy 12(1): 83-102.

Foucault, Michel. 1969. Larchéologie du Savoir. Paris: Gallimard.

Foucault, Michel. 1975. Surveiller et punir. Paris: Gallimard.

Gafaranga, Joseph. 2011. Transition space medium repair: Language shift talked into being. Journal of Pragmatics 43(1): 118-135.

Gallo, Sarah and Nancy H. Hornberger. 2017. Immigration policy as family language policy: Mexican immigrant children and families in search of biliteracy. International Journal of Bilingualism doi: 10.1177/1367006916684908.

García, Ofelia, and Li Wei. 2014. Translanguaging: Language, Bilingualism and Education. Basingstoke: Palgrave Macmillian

García, Ofelia, Nelson Flores, and Massimiliano Spotti. (2017). Introduction - Language and Society: A critical poststructuralist perspective. In Ofelia García, Nelson Flores, and Massimiliano Spotti (eds). The Oxford Handbook of Language and Society. Oxford: Oxford University Press. 1-20.

Grue, Jan (2016). The social meaning of disability: A reflection on categorisation, stigma and identity. Sociology of Health and Illness 38(6): 957-964.

Gyogi, Eiko. 2015. Children's agency in language choice: a case study of two 
Japanese-English bilingual children in London. International Journal of Bilingual Education and Bilingualism 18(6): 749-764.

Harris, Tracy K. 1982. Editor's note: The name of the language of Eastern Sephardim. International Journal of Sociology of Language 37: 5.

Haugen, Einar. 1972. The Ecology of Language: Essays. California: Stanford University Press.

He, Agnes Weiyun. 2016. Discursive roles and responsibilities: A study of interactions in Chinese immigrant households. Journal of Multilingual and Multicultural Development 37(7): 667-679.

Heller, Monica. 2011. Paths to PostNationalism: A Critical Ethnography of Language and Identity. Oxford: Oxford University Press.

Hinton, Leanne (ed). 2013. Bringing our Languages Home: Language Revitalization for Families. Berkeley: Heyday.

Hornberger, Nancy H. 2002. Multilingual language policies and the continua of biliteracy: An ecological approach. Language Policy 1(1): 27-51.

Hornberger, Nancy H. and David Cassels Johnson. 2011. The ethnography of language policy. In Teresa L. McCarty (ed). Ethnography and Language Policy. New York: Routledge. 273-289.

Hult, Francis M. and David Cassels Johnson. 2015. Research Methods in Language Policy and Planning: A Practical Guide. Chichester: Wiley Blackwell.

Jaspers, Jürgen and Lian Malai Madsen. 2016. Sociolinguistics in a languagised world: Introduction. Applied Linguistics Review, 7(3): 235-258.

Johnson, David Cassels and Thomas Ricento. 2013. Conceptual and theoretical perspectives in language planning and policy: Situating the ethnography of language policy. International Journal of the Sociology of Language 219: 7-21.

Jørgensen, J. Normann. 2008. Polylingual languaging around and among children and adolescents. International Journal of Multilingualism 5(3): 161-176.

Kang, Hyun-Sook. 2015. Korean families in America: Their family language policies and home-language maintenance. Bilingual Research Journal 38(3): 275-291.

Kaveh, Yalda M. 2017. Family language policy and maintenance of Persian: The stories of Iranian immigrant families in the northeast, USA. Language Policy 1-35 doi: https://doi.org/10.1007/ s10993-017-9444-4.

Kayam, Orly and Tijana Hirsch. 2014. Socialization of language through family language policy: A case study. Psychology of Language and Communication 18(1): 53-66.

Kendrick, Maureen and Elizabeth Namazzi. 2017. Family language practices as emergent policies in child-headed households in rural Uganda. In John Macalister and Seyed Hadi Mirvahedi (eds). Family Language Policies in a Multilingual World: Opportunities, Challenges, and Consequences. New York: Routledge. 56-73.

Kerfoot, Caroline and Kenneth Hyltenstam. 2017. Introduction: Entanglement and orders of visibility. In Caroline Kerfoot and Kenneth Hyltenstam (eds). Entangled Discourses: South-North Orders of Visibility. New York: Routledge. 11-26.

Kheirkhah, Mina and Asta Cekaite. 2015. Language maintenance in a multilingual family: Informal heritage language lessons in parent-child interactions. Multilingua 34(3): 319-346.

Khubchandani, Lachman M. 1983. Plural Languages, Plural Cultures: Communication, Identity, and Sociopolitical Change in Contemporary India. Honolulu: University of Hawaii Press.

Kim, Sun Hee Ok and Donna Starks. 2010. The role of fathers in language maintenance and language attrition: The case of Korean-English late bilinguals in New Zealand. International Journal of Bilingual Education and Bilingualism 13(3): 285-301.

King, Kendall A. 2016. Language policy, multilingual encounters, and transnational families. Journal of Multilingual and Multicultural Development 37(7): 726-733.

King, Kendall A. and Lyn Wright Fogle. 2013. Family language policy and bilingual parenting. Language Teaching, 46(2): 172-194. 
King, Kendall and Elizabeth Lanza. 2017. Ideology, agency, and imagination in multilingual families: An introduction. International Journal of Bilingualism 1-7 doi: https://doi. org/10.1177/1367006916684907.

King, Kendall A., Lyn Fogle, and Aubrey Logan-Terry. 2008. Family language policy. Language and Linguistics Compass 2(5): 907-922.

Kopeliovich, Shulamit. 2010. Family language policy: A case study of a Russian-Hebrew bilingual family: Toward a theoretical framework. Diaspora, Indigenous, and Minority Education 4(3): 162-178.

Kymlicka, Will. 1995. Multicultural Citizenship: A Liberal Theory of Minority Rights. Oxford: Clarendon Press.

Lane, Pia. 2010. "We did what we thought was best for our children": A nexus analysis of language shift in a Kven community. International Journal of Social Language 202: 63-78.

Lanza, Elizabeth. 2007. Multilingualism and the family. In Li Wei and Peter Auer (eds). Handbook of Multilingualism and Multilingual Communication. Berlin: Mouton de Gruyter. 45-67.

Lefebvre, Henri. 1991. The Production of Space. Oxford: Blackwell.

Levon, Erez. 2017. Situating sociolinguistics: Coupland - Theoretical Debates. Journal of Sociolinguistics 21(2): 272-288.

Li Wei. 2012. Language policy and practice in multilingual, transnational families and beyond. Journal of Multilingual and Multicultural Development 33(1): 1-2.

Li Wei. 2018. Translanguaging as a practical theory of language. Applied Linguistics 39(1): 9-30.

Lomeu Gomes, Rafael. forthcoming. Family multilingualism through a southern perspective: (Self)positioning of Brazilian parents in intercultural encounters in Norway.

Martin-Jones, Marilyn and Deirdre Martin (eds). 2016. Researching multilingualism: critical and ethnographic perspectives. London: Routledge.

McKee, Rachel and Kirsten Smiler. 2017. Family language policy for deaf children and the vitality of New Zealand Sign Language. In John Macalister and
Seyed Hadi Mirvahedi (eds). Family Language Policies in a Multilingual World: Opportunities, Challenges, and Consequences. New York: Routledge. 30-55.

Mesthrie, Rajend and Ana Deumert. 2000. Critical sociolinguistics: Approaches to language and power. In Rajend Mesthrie, Joan Swann, Ana Deumert and William L. Leap (eds). Introducing Sociolinguistics. 316-353.

Mignolo, Walter. D. 2011 a. Geopolitics of sensing and knowing: on (de)coloniality, border thinking and epistemic disobedience. Postcolonial Studies 14(3): 273-283.

Mignolo, Walter D. 2011 b. The Darker Side of Western Modernity: Global Futures, Decolonial Options. Durham: Duke University Press.

Milani, Tommaso M. (ed.) 2018. Queering Language, Gender and Sexuality. Sheffield: Equinox.

Milani, Tommaso M. and Michelle M. Lazar. 2017. Seeing from the South: Discourse, gender and sexuality from southern perspectives. Journal of Sociolinguistics, 21(3): 307-319.

Mirvahedi, Seyed. 2017. Exploring family language policies among Azerbaijanispeaking families in the city of Tabriz, Iran. In John Macalister and Seyed Hadi Mirvahedi (eds). Family Language Policies in a Multilingual World: Opportunities, Challenges, and Consequences. New York: Routledge. 74-95.

Moore, Leslie C. 2016. Change and variation in family religious language policy in a West African Muslim community. Language Policy 15(2): 125-139.

Møller, Janus Spindler and J. Normann Jørgensen. (2009). From language to languaging: Changing relations between humans and linguistic features. Acta Linguistica Hafniensia 41(1): 143-166.

Nakamura, Janice. 2016. Hidden bilingualism: Ideological influences on the language practices of multilingual migrant mothers in Japan. International Multilingual Research Journal 10(4): 308-323.

Ó hIfearnáin, Tadhg. 2013. Family language policy, first language Irish speaker attitudes and community-based response 
to language shift. Journal of Multilingual and Multicultural Development 34(4): 348-365.

Oriyama, K. 2016. Community of practice and family language policy: Maintaining heritage Japanese in Sydney-Ten years later. International Multilingual Research Journal 10(4): 289-307.

Orman, Jon. 2013. New lingualisms, same old codes. Language Sciences 37: 90-98.

Otheguy, Ricardo, Ofelia García, and Wallis Reid. 2015. Clarifying translanguaging and deconstructing named languages: A perspective from linguistics. Applied Linguistics Review 6(3): 281-307.

Otsuji, Emi and Alastair Pennycook. 2010. Metrolingualism: Fixity, fluidity and language in flux. International Journal of Multilingualism 7(3): 240-54.

Parada, Maryann. 2013. Sibling variation and family language policy: The role of birth order in the Spanish proficiency and first names of second-generation Latinos. Journal of Language, Identity $\mathcal{E}^{\circ}$ Education 12(5): 299-320.

Patrick, Donna, Gabriele Budach and Igah Muckpaloo. 2013. Multiliteracies and family language policy in an urban Inuit community. Language Policy 12(1): 47-62.

Pennycook, Alastair. 2001. Critical Applied Linguistics: A Critical Introduction. Mahwah, NJ: Lawrence Erlbaum.

Pennycook, Alastair. 2004. Critical applied linguistics. In Alan Davies and Catherine Elder (eds). The Handbook of Applied Linguistics. Oxford: Blackwell Publishing. 784-807.

Pennycook, Alastair. 2016. Mobile times, mobile terms: The trans-super-polymetro movement. In Nikolas Coupland (ed). Sociolinguistics: Theoretical Debates. Cambridge: Cambridge University Press. 201-216.

Pennycook, Alastair. 2017. Language policy and local practices. In Ofelia García, Nelson Flores, and Massimiliano Spotti (eds). The Oxford Handbook of Language and Society. Oxford: Oxford University Press. 125-146.

Pennycook, Alastair and Emi Otsuji. 2015. Metrolingualism: Language in the City. London: Routledge.

Pérez Báez, Gabriela. 2013. Family language policy, transnationalism, and the diaspora community of San Lucas Quiaviní of Oaxaca, Mexico. Language Policy 12(1): 27-45.

Pietikäinen, Sari. 2016. Critical debates:

Discourse, boundaries and social change. In Nikolas Coupland (ed). Sociolinguistics: Theoretical Debates. Cambridge: Cambridge University Press. 263-281.

Pillai, Stefanie, Wen-Yi Soh, and Angela S. Kajita. 2014. Family language policy and heritage language maintenance of Malacca Portuguese Creole. Language $\mathcal{F}^{\circ}$ Communication 37: 75-85.

Purkarthofer, Judith. 2017. Building expectations: Imagining family language policy and heteroglossic social spaces. International Journal of Bilingualism doi: https://doi. org/10.1177/1367006916684921.

Quijano, Aníbal. 1989. Colonialidad y modernidad/racionalidad. In Heraclio Bonilla (ed.). Los conquistados. 1492 y la población indígena de las Américas. Ecuador: Libri Mundi, Tercer Mundo Editores. 437-448.

Rampton, Ben. 2012. A neo-Hymesian trajectory in applied linguistics. Applied Linguistics Review 3(2): 233-249.

Ren, Li and Guangwei Hu. 2013. Prolepsis, syncretism, and synergy in early language and literacy practices: a case study of family language policy in Singapore. Language Policy 12(1): 63-82.

Revis, Melanie. 2016. A Bourdieusian perspective on child agency in family language policy. International Journal of Bilingual Education and Bilingualism doi: 10.1080/13670050.2016.1239691

Reyes, Angela. 2017. Inventing postcolonial elites: Race, language, mix, excess. Journal of Linguistic Anthropology 27(2): 210-231.

Ricento, Thomas. 2000. Historical and theoretical perspectives in language policy and planning. Journal of Sociolinguistics, 4(2): 196-213.

Roberts, Celia. 2001. 'Critical' social theory: Good to think with or something more? In Nikolas Coupland, Srikant Sarangi, Christopher N. Candlin (eds). Sociolinguistics and Social Theory. Harlow: Pearson Education Limited. 323-333.

Rosa, Jonathan, and Nelson Flores. 2017. Unsettling race and language: Toward a 
raciolinguistic perspective. Language in Society 46(5): 621-647.

Samy Alim, H., John R. Rickford, and Arnetha F. Ball. 2016. Raciolinguistics: How Language Shapes our Ideas about Race. New York: Oxford University Press.

Santos, Boaventura de Sousa. 2007. Beyond abyssal thinking: From global lines to ecologies of knowledges. Review (Fernand Braudel Center) 30(1): 45-89.

Santos, Boaventura de Sousa. 2014. Epistemologies of the South. Justice against Epistemicide. Boulder: Paradigm Publishers.

Santos, Boaventura de Sousa. 2018. The End of the Cognitive Empire: The Coming of Age of Epistemologies of the South. Durham: Duke University Press.

Santos, Milton. 2017. Toward an Other Globalization: From the Single Thought to Universal Conscience. Translated by Lucas Melgaço and Tim Clarke. London: Springer.

Schiefflin, Bambi and Elinor Ochs. 1986. Language socialization. Annual Review of Anthropology 15: 163-191.

Schiffman, Harold. 1996. Linguistic culture and language policy. London: Routledge.

Schwartz, Mila. 2008. Exploring the relationship between family language policy and heritage language knowledge among second generation RussianJewish immigrants in Israel. Journal of Multilingual and Multicultural Development 29(5): 400-418.

Schwartz, Mila. 2010. Family language policy: Core issues of an emerging field. Applied Linguistics Review 1: 171-192.

Schwartz, Mila Anna Verschik (eds). 2013. Successful Family Language Policy: Parents, Children and Educators in Interaction. Dordrecht: Springer.

Seloni, Lisya and Yusuf Sarfati. 2013. (Trans) national language ideologies and family language practices: a life history inquiry of Judeo-Spanish in Turkey. Language Policy 12(1): 7-26.

Shohamy, Elana. 2006. Language Policy: Hidden Agendas and New Approaches. London: Routledge.

Slavkov, Nicolay. 2016. Family language policy and school language choice: pathways to bilingualism and multilingualism in a Canadian context.
International Journal of Multilingualism doi: 10.1080/14790718.2016.1229319

Smith-Christmas, Cassie. 2014. Being socialised into language shift: the impact of extended family members on family language policy. Journal of Multilingual and Multicultural Development 35(5): 511-526.

Smith-Christmas, Cassie. 2016. Family Language Policy: Maintaining an Endangered Language in the Home. Basingstoke: Palgrave Macmillan.

Smith-Christmas, Cassie. 2017. Family language policy: New directions In John Macalister and Seyed Hadi Mirvahedi (eds). Family Language Policies in a Multilingual World: Opportunities, Challenges, and Consequences. New York: Routledge. 23-39.

Spolsky, Bernard. 2004. Language Policy. Cambridge: Cambridge University Press.

Spolsky, Bernard. 2007. Towards a theory of language policy. Working Papers in Educational Linguistics 22(1): 1-14.

Spolsky, Bernard. 2009. Language Management. Cambridge: Cambridge University Press.

Spolsky, Bernard. 2012. Family language policy-the critical domain. Journal of Multilingual and Multicultural Development 33(1): 3-11.

Stavans, Anat. 2015. Enabling bi-literacy patterns in Ethiopian immigrant families in Israel: a socio-educational challenge. International Journal of Multilingualism 12(2): 178-195.

Tannenbaum, Michal. 2012. Family language policy as a form of coping or defence mechanism. Journal of Multilingual and Multicultural Development 33(1): 57-66.

Tannenbaum, Michal. and Dafna Yitzhaki. 2016. 'Everything comes with a price...'; family language policy in Israeli Arab families in mixed cities. Language and Intercultural Communication 16(4): 570-587.

Veronelli, Gabriela A. 2015. Sobre la colonialidad del lenguaje. Universitas Humanística 81: 33-58.

Wallerstein, Immanuel. (1991). Unthinking Social Science. Cambridge: Polity Press.

Wenger, Etienne. 1998. Communities of Practice: Learning, Meaning, and Identity. Cambridge: Cambridge University Press. 
Williams, Quentin E. and Christopher Stroud. 2014. Battling race: stylizing language and the coproduction of whiteness and colouredness in a freestyle rap battle. Journal of Linguistic Anthropology 24(3): 277-293.

Xiaomei, Wang. 2017. Family language policy by Hakkas in Balik Pulau, Penang. International Journal of the Sociology of Language 244: 87-118.

Yu, Betty. 2016. Bilingualism as conceptualized and bilingualism as lived: A critical examination of the monolingual socialization of a child with autism in a bilingual family. Journal of Autism and Developmental Disorders 46(2): 424-435.

Zhu Hua and Li Wei. 2016. Transnational experience, aspiration and family language policy. Journal of Multilingual and Multicultural Development 37(7): 655-666. 